\title{
El EXTREMISMO POLÍTICO EN ESCANDINAVIA... ¿OCASO DE LA SOCIALDEMOCRACIA?
}

\author{
POLITICAL EXTREMISM IN SCANDINAVIA... \\ THE TWILIGHT OF SOCIAL DEMOCRACY?
}

\section{L'EXTRÉMISME POLITIQUE EN SCANDINAVIE SIGNALE-T-IL LE CRÉPUSCULE DE LA SOCIAL-DÉMOCRATIE?}

\author{
Omar García Olascoaga \\ Universidad Nacional Autónoma de México \\ olascoaga@comunidad.unam.mx
}

\begin{abstract}
Resumen: Hace poco que los países nórdicos han atestiguado la irrupción de los partidos de extrema derecha en sus recintos parlamentarios, a más de verlos incorporarse como socios, por ejemplo, de Dinamarca, Finlandia y Noruega. Este fenómeno político es el resultado de dos factores: primero, la ineficacia de la gestión socialdemócrata para solucionar los problemas que afectan a los ciudadanos y, segundo, el compromiso que ha asumido la extrema derecha populista con el gobierno en turno. Con todo, Suecia es la única nación escandinava que aún no ha permitido al radicalismo político participar del gobierno, aunque nadie sabe por cuánto tiempo más.

Palabras clave: Extremismo político, etnonacionalismo, socialdemocracia, populismo, Escandinavia.
\end{abstract}

Abstract: Recently, the Nordic countries have witnessed the emergence of farright parties in their parliaments, and even seeing them join as partners in government, for example, in Denmark, Finland and Norway. This political phenomenon is the result of two factors: first, the ineffectiveness of social democratic policies to solve the problems affecting citizens and, second, the commitment that the populist extreme right has made to the government in turn. Nevertheless, Sweden is the only Scandinavian nation that has not yet allowed political radicalism to participate in the government, although no one knows for how much longer. 
Keywords: Political extremism, ethno-nationalism, social-democracy, populism, Scandinavia.

\section{Traducción de Gonzalo Celorio Morayta}

Résumé: Les pays scandinaves ont vu récemment l'arrivée à leurs parlements de partis d'extrême droite, qui se sont même joints à des coalitions au Danemark, en Finlande et en Norvège. Ce phénomène politique est le résultat de deux éléments, dont l'un est l'inefficacité de la social-démocratie à résoudre les problèmes qui touchent les citoyens, l'autre est l'accord de l'extrême droite populiste avec les gouvernements au pouvoir. Désormais, la Suède est la seule nation scandinave qui n'a toujours pas permis au radicalisme politique de participer au gouvernement, mais personne ne sait combien de temps cela pourrait encore durer.

Mots clefs: Extrémisme politique, ethnonationalisme, social-démocratie, populisme, Scandinavie.

Traducción de Bernardo Mabire

Fecha de recepción: noviembre de 2017

Fecha de aceptación: mayo de 2018 
$\mathrm{E}$ L EXTREMISMO POLítico hoy día es una realidad incuestionable en los países nórdicos. Durante varias décadas, las capas de hielo contuvieron el crecimiento de las raíces del nacionalismo étnico en Escandinavia. Empero, la primavera populista y xenófoba se ha extendido a las tierras boreales, en cuyos paisajes, una vez más, brotan las anémonas azules, ${ }^{1}$ particularmente en el último bastión socialdemócrata: Suecia. Ninguna democracia nórdica, hasta ahora, ha permanecido ajena a la xenofobia expuesta por esta familia política, la cual se ha encargado de inocular un discurso de exclusión para con lo extraño y lo atípico, a pesar de sobresalir por su bienestar económico y progreso social.

En los setenta, los partidos progresistas -populistas y antisistémicos- nacieron simultáneamente en Dinamarca y Noruega e ingresaron, por primera vez, a los recintos parlamentarios en 1973. Más tarde, tras la efímera estancia de Nueva Democracia en el parlamento en 1991, los Demócratas Suecos ganaron sus primeros escaños hasta las elecciones de 2010, mientras que los Auténticos Finlandeses (hoy rebautizados como Los Finlandeses) multiplicaron sus votos en la contienda de 2011. Islandia, por el contrario, es el único país nórdico donde estos partidos todavía no son relevantes, aunque estén representados por el Frente Nacional Islandés y el Partido del Pueblo.

A poco de haber comenzado el siglo que corre, el voto por la extrema derecha propició una mayor presencia en el gobierno junto con los partidos tradicionales -liberales y conservadores- en Dinamarca, Noruega y Finlandia. El único caso en el cual todavía no se ha infiltrado en el gobierno es Suecia. Sin embargo, Los Moderados hace poco amenazaron con romper el cordón sanitario impuesto en contra de los Demócratas Suecos para negociar un acuerdo político paulatino en vísperas de las elecciones parlamentarias del

${ }^{1}$ Desde 2006, la anémona azul, flor típica en Escandinavia, se convirtió en la insignia de los Demócratas Suecos. 
2018, con el fin de derrocar a la actual coalición rojiverde encabezada por la socialdemocracia. ${ }^{2}$

Se reconoce a los países nórdicos internacionalmente por ser las sociedades más prósperas, avanzadas y pacíficas. Cada año, estos países ocupan los primeros lugares en los índices que evalúan la riqueza, la educación y la paz. ${ }^{3}$ Asimismo, el Estado de bienestar impulsado por la socialdemocracia en la posguerra representa el modelo de asistencia social que goza de mayor popularidad en el mundo a causa de la extensa red de prerrogativas que proporciona el Estado. Paradójicamente, la prosperidad de estas naciones contrasta con un hecho: el rebrote del nacionalismo, la xenofobia y el racismo, cuyo reclamo se centra en beneficiar exclusivamente a los nativos con el propósito de preservar la homogeneidad de los pueblos escandinavos.

Las raíces del extremismo político en Europa se remontan al periodo de entreguerras. No obstante lo cual, el régimen fascista se enraizó en Escandinavia, región donde prevalecieron los gobiernos constitucionales bajo la bandera de la neutralidad. Sin embargo, los vientos de la época no se contuvieron en la Europa Centro-Oriental y se expandieron también hasta el gélido norte. En esta etapa, nacieron varios partidos simpatizantes del régimen de Hitler: el Partido Fascista del Pueblo de Suecia (1926-1930), el Partido Nacional Socialista Sueco (1930-1936), el Partido Clerical del Pueblo (1930-1936), el Partido Nacionalsocialista Obrero de Dinamarca (1930-1945), el Movimiento Lapua (1929-1931), el Movimiento Popular Patriótico (1932-1944), el Bloque Nacionalsocialista (1933-1936),

${ }^{2}$ En abril de 2018, El Electoral promedió la siguiente votación: el Partido Socialdemócrata $(26.4 \%)$, Los Moderados $(22.4 \%)$ y los Demócratas Suecos (17.5\%). Véase en http://elelectoral.com/internacional/ suecia/, consultado el 12.V.2018.

3 Según el índice "Better Life" de la ocDE, las sociedades nórdicas ocupan los primeros lugares en materia de bienestar a través de las condiciones de vida material y la calidad de vida. Véase oEcD, How's Life? 2015. Measuring Well-being, París, oEcD Publishing, 2015, en http://www.oecd. org/statistics/how-s-life-23089679.htm, consultado el 4.X.2017. 
la Unidad Nacional (1933-1945) y el Partido Nacionalsocialista Obrero Sueco (1933-1950). Salvo Finlandia, cuyo partido fascista recogió una modesta votación en 1936 y 1939, el comportamiento electoral de los movimientos fascistas en el resto de Escandinavia fue lamentable. ${ }^{4}$

Después de 1945, los países nórdicos entraron en una época de estabilidad política y crecimiento económico por la imparcialidad ante los Aliados y las Potencia del Eje. Mientras Europa se reconstruía bajo los escombros del Tercer Reich, Escandinavia aprovechó la etapa de oro capitalista -conocida también como los Treinta Gloriosos- para extender el Estado de bienestar, producto de una estricta recaudación fiscal. Sin embargo, este periodo de bonanza se interrumpió en los setenta con la conclusión de los Acuerdos de Bretton Woods y la crisis del petróleo. La reestructuración del sistema de producción capitalista y las nuevas condiciones socioeconómicas en el mercado laboral aceleraron la aparición de fenómenos propios de la globalización económica, como la inmigración y el desempleo.

A pesar de la imposición de cordones sanitarios por el sistema de partidos para excluirlos de la escena política, la extrema derecha ha popularizado con éxito el discurso xenófobo y racista en las sociedades más progresistas, plurales y tolerantes, a grado tal que una sexta parte de la ciudadanía vota hoy día por su programa electoral. ${ }^{5}$ Recientemente, las coaliciones de gobierno entre conservadores y liberales han accedido a sus reclamos en busca de una mayor legitimidad social y estabilidad política. Este artículo sostiene que el éxito de los partidos etnonacionalistas se debe a que la socialdemocracia continúa siendo flexible respecto a la entrada de los extranjeros en un caldo de cultivo óptimo para la política de p. 90 .

${ }^{4}$ P. Morgan, Fascism in Europe, 1919-1945, Londres, Routledge, 2003,

${ }^{5}$ En las últimas elecciones, estos partidos han obtenido los siguientes resultados: los Demócratas Suecos 12.9\% (2014), Los Finlandeses 17.6\% (2015), el Partido Popular Danés 21.1\% (2015) y el Partido del Progreso Noruego $15.2 \%$ (2017). 
exclusión, pero también a que ha cooperado responsablemente desde la oposición con el gobierno en turno.

\section{LA CONCEPCIÓN DEL EXTREMISMO POLÍTICO}

Es fama que Eric Hobsbawn nombró el siglo xx como "la era de los extremos" (1914-1991), durante la cual se registraron los regímenes más violentos para la historia de la humanidad: el Comunismo, el Fascismo, el Nazismo. Después de la caída del Antiguo Régimen, la época contemporánea ha presenciado la aparición de un cúmulo de movimientos -tanto de izquierda como de derecha-, catalogados bajo la etiqueta de extremistas: los jacobinos de la Revolución Francesa, los bolcheviques de la Revolución Rusa, los fascistas del Reino de Italia, los nazis del Tercer Reich y se han agregado a éstos recientemente los fundamentalistas del Estado Islámico. Esta multiplicidad de casos representa una encrucijada para los investigadores, quienes no han llegado a un consenso respecto a una definición unívoca.

La bibliografía sobre el extremismo se remonta hasta la Antigua Grecia y ha transitado por varias etapas hasta el presente. Pero éste no es el espacio para profundizar respecto a sus orígenes, su evolución, los debates conceptuales, ni mucho menos para elaborar una definición sobre el tema. ${ }^{6}$ Sin embargo, para los objetivos del presente artículo, resulta indispensable establecer, por lo menos, qué se entiende por extremismo político, no menos que apuntar la variedad de fenómenos que se han catalogado bajo este término y exponer, en fin, los elementos básicos que comprende este concepto en la perspectiva de los países nórdicos.

${ }^{6}$ Para profundizar en el tema, el lector puede recurrir a los libros de A. Breton et al. (eds.), Political Extremism and Rationality, Nueva York, Cambridge University Press, 2002; U. Backes y J. Eckhard (eds.), Vergleichende Extremismusforschung, Baden-Baden, Nomos, 2005; R. Wintrobe, Rational Extremism. The Political Economy of Radicalism, Cambridge, University Press, 2006, y C. Mudde (ed.), Political Extremism, Londres, Sage, 2014. 
En primer lugar, Manus I. Midlarsky concluye que extremismo político es "la voluntad de poder de un movimiento social al servicio de un programa político típicamente en oposición a las autoridades estatales existentes y para el cual las libertades individuales deben reducirse en nombre de los objetivos colectivos, incluyendo el asesinato masivo de aquellos que no coinciden con el programa". ${ }^{7}$ Esta propuesta conceptual retrata mejor a los regímenes totalitarios del siglo $\mathrm{xx}$, los cuales recurrieron a prácticas inhumanas como el exterminio social y el biológico para justificar la permanencia del Estado. ${ }^{8}$ Pero Midlarsky recalca en un inicio que los extremistas son intolerantes, puesto que a menudo discrepan del punto de vista del poder establecido, por lo que buscan alcanzar sus objetivos por medio de métodos más radicales como la violencia e incluso el terrorismo. Sobre este punto, cabe resaltar que el extremismo y el terrorismo se asocian muy a menudo, aunque se los considere objetos de estudio independientes, razón por la cual los partidos nacionalistas nórdicos pueden ser catalogados como extremistas, pero sin tenerse por terroristas. ${ }^{9}$

Para distinguir las múltiples manifestaciones extremistas, Midlarsky las clasifica en cuatro categorías: el Fascismo, el Comunismo, el Islamismo radical y el Nacionalismo extremo. Este último, apunta el autor, se diferencia notablemente de

${ }^{7}$ Origins of Political Extremism. Mass Violence in the Twentieth Century and Beyond, Cambridge, University Press, 2011, p. 7.

${ }^{8}$ Véase E. Nolte y G. Muñoz, "Un pasado que no quiere pasar. Una conferencia que, ya escrita, no pudo ser pronunciada”, Pasajes. Revista de pensamiento contemporáneo, núm. 24, 2007, pp. 71-75.

${ }^{9} \mathrm{El}$ terrorismo es una práctica condenada por los partidos nacionalistas en Escandinavia; sin embargo, los actos de violencia recurrentemente están respaldados por su militancia, la cual está vinculada con grupos paramilitares y neonazis, como el Movimiento de Resistencia Nórdico, los Soldados de Odin, las Juventudes Nórdicas, Vigrid, la Liga de la Defensa Europea y los Patriotas Europeos contra la islamización de Occidente, cuyo propósito consiste en combatir a los creyentes de Alá radicados en los países nórdicos. 
los otros tres tipos; sin embargo, hay que recalcarlo, el discurso nacionalista siempre es la raíz de todo régimen totalitario, el cual se torna extremo, si hay una amenaza que atente contra la integridad del Estado. Estos partidos nacionalistas justifican su postura xenófoba y racista, puesto que consideran un peligro latente la "invasión extranjera" acaecida en las últimas décadas en Escandinavia. Al respecto, Uwe Backes señala que el extremismo es un término estigmatizado, "utilizado para marcar límites de legitimidad política, juzgar a otros indignos y designar los peligros". ${ }^{10}$

El extremismo político se presenta en múltiples facetas, pero engloba a todos aquellos grupos e ideologías que promueven una visión radicalmente antipluralista, promotora de una comunidad nacional homogénea y contraria a los valores democráticos básicos. ${ }^{11}$ Los partidos de extrema derecha son antidemocráticos, no porque no respeten las reglas del juego, ni la institucionalidad, ni porque proclamen el exterminio de un grupo social, sino porque rechazan el principio fundamental de la igualdad humana. Entonces, apunta G. Bingham Powell,

un partido extremista exhorta a la transformación de la sociedad, hacia una visión futura o hacia un pasado idealizado. Dichas peticiones contrastan con el consenso de la política actual; su presencia obstruye severamente la capacidad para reconciliar intereses que brotan del sistema político. Desde esta perspectiva, los partidos extremistas son aquellos que enarbolan sus propuestas articuladamente, en oposición a las que exponen la mayoría de los partidos. ${ }^{12}$

10 Political Extremes. A Conceptual History from Antiquity to the Present, Londres, Routledge, 2011, p. 178.

${ }^{11}$ R. Pankowski, The Populist Radical Right in Poland: The Patriots, Londres, Routledge, 2011, p. 4.

12 "Extremist Parties and Political Turmoil: Two Puzzles", American Journal of Political Science, vol. 30, núm. 2, 1986, pp. 358-359. 


\section{ETAPAS DEL EXTREMISMO POLÍTICO EN LOS PAÍSES NÓRDICOS}

Actualmente, los partidos de extrema derecha concurren en los parlamentos nórdicos, consolidándose entre las primeras tres fuerzas políticas. Pero su retorno no fue espontáneo, sino el colofón de un largo proceso histórico. En su estudio seminal, Seymour M. Lipset y Stein Rokkan concluyeron que la aparición de partidos en Europa Occidental se había estabilizado en la Posguerra:

Los sistemas de partidos de los sesenta reflejan, con escasas pero significativas excepciones, las estructuras de división de los veinte... Las alternativas partidistas son más viejas que gran parte del electorado. Para la mayoría de los ciudadanos en Occidente, los partidos activos de hoy forman parte del paisaje político desde su infancia o desde que enfrentaron por primera vez el problema de elegir entre «paquetes» alternativos en unas elecciones. ${ }^{13}$

Sin embargo, esta práctica cambió en la era del posmaterialismo, cuando nacieron dos nuevas familias: los movimientos verdes y la derecha radical populista. ${ }^{14}$

Según Klaus von Beyme, el extremismo político en Europa ha recorrido tres etapas en la Posguerra: el Neofascismo (19451952), la Protesta antisistémica (1953-1979) y la Crisis económica (de 1980 al presente). ${ }^{15}$ Sin embargo, esta última ha sido superada con el paso del tiempo, puesto que en ella se ha gestado un cuarto periodo que nace alrededor del año 2000, precisamente cuando estos partidos políticos se presentan

13 "Cleavage Structures, Party Systems, and Voter Alignments: An Introduction", en S. M. Lipset y S. Rokkan (eds.), Party Systems and Voter Alignments: Cross-National Perspectives, Nueva York, The Free Press, 1967, p. 50.

${ }^{14}$ C. Mudde, Populist Radical Right Parties in Europe, Cambridge, University Press, 2007, p. 1.

15 "Right-Wing Extremism in Post-War Europe", West European Politics, vol. 11, núm. 2, 1988, pp. 6-13. 
frente a los electores como una opción real de gobierno y acceden al ejercicio del poder político en varias democracias de Europa, etapa catalogada como la de su legitimación política. ${ }^{16}$

La primera fase fue casi inexistente en los países nórdicos. Históricamente, el Fascismo nunca se emuló en Escandinavia como en el resto de Europa: no fue un fenómeno de masas, ni tampoco surgió un líder carismático, como Mussolini, Hitler o Franco, ni mucho menos hubo un régimen de partido único. Es cierto que en el periodo de entreguerras nacieron varios partidos fascistas, pero éstos nunca representaron un peligro para la democracia. Esto tiene una explicación. En la Segunda Guerra Mundial, Hitler les confirió una relativa independencia y respetó su vida institucional a cambio de no obstruir los intereses de las Potencias del Eje. Noruega fue el único caso en que el Fascismo gobernó mediante un golpe de Estado, cuando Vidkun Quisling estableció un régimen colaboracionista tras la invasión nazi de 1940. Sin embargo, Europa fue desnazificada en 1945 con los Juicios de Núremberg y Escandinavia no fue la excepción. Las raíces fascistas fueron erradicadas, salvo en Suecia, donde los neonazis se refugiaron en instancias como la Oposición Sueca, el Nuevo Movimiento Sueco, la Unidad Socialista Sueca y el Partido del Reich Nórdico, pero sin trasgredir los principios liberales.

Esta historia cambió en la segunda etapa. Antecedido por el Qualunquismo en Italia y el Poujadismo en Francia, el populismo antisistémico nació en estos países en los sesenta. Durante las negociaciones para ingresar en la Comunidad Económica Europea, los partidos progresistas surgieron casi simultáneamente en Suecia, Dinamarca y Noruega. ${ }^{17}$ En

16 Véase A. Widfeldt, "A Fourth Phase of the Extreme Right? Nordic Immigration-critical Parties in a Comparative Context", NORDEUROPAforum, vol. 20, núm. 1, 2010, pp. 7-31, y O. García Olascoaga, Los partidos etnonacional populistas: una explicación para entender su comportamiento electoral en las democracias europeas contemporáneas, tesis, México, FCPys-unAm, 2016.

17 En la literatura, Ignazi los ha catalogado como "casos dudosos"; Kitschelt y McGann, como "versiones suaves"; y Cas Mudde no los ubica en los "casos límite". No obstante, en los años ochenta, estos partidos adopta- 
1968, Bertil Rubin, otrora militante del Partido del Centro, fundó el Partido del Progreso Sueco (FSP), pero nunca lo consolidó nacionalmente, participando sólo en el ámbito local. Tras su refundación en 1979, una escisión del FsP y el movimiento Preservar a Suecia Sueca coincidieron en el Partido Sueco en 1986. Por su parte, en 1972, el Partido del Progreso Danés (FKP), instancia neoliberal y contraria a los impuestos y la burocracia, irrumpió en Dinamarca, cuando su líder, Mogens Glistrup, reconoció no tributar, presentando a su partido como anarcoliberal y antielitista. ${ }^{18}$ Por la evasión fiscal, Glistrup fue a la cárcel, hecho que aprovechó Pia Kjærsgaard para ocupar la presidencia del FKP en 1985. Por último, los orígenes del Partido del Progreso Noruego (FRP), cuyo nombre original fue Partido de Anders Lange por una Fuerte Reducción de Impuestos, Deberes e Intervención Pública, se remontan a 1973. En sus inicios, Lange lo presentó como un partido populista, autoritario y antisistémico, ${ }^{19}$ pero, tras su repentina muerte en 1974, el FRP perdió todas sus curules, periodo de crisis que culminó con la presidencia de Carl I. Hagen en 1978. ${ }^{20}$ Los comicios de 1973 representaron un sismo político para la democracia en Dinamarca y Noruega, porque, por primera vez, los partidos populistas ingresaron en los parlamentos con un programa antisistémico y en contra de la gestión socialdemócrata. Sin embargo, su fuerza electoral fue volátil y

ron una retórica xenófoba y racista, posición que los acredita como parte de esta familia política. Véase P. Ignazi, "The Silent Counter Revolution: Hypotheses on the Emergence of Extreme Right-wing Parties in Europe", European Journal of Political Research, vol. 22, núm. 1, 1992, pp. 3-34; H. Kitschelt y A. J. McGann, The Radical Right in Western Europe: A Comparative Analysis, Ann Arbor, University of Michigan Press, 1995; y C. Mudde, op. cit.

18 J. G. Andersen, The Danish People's Party and New Cleavages in Danish Politics, Aalborg, Aalborg Universitet, 2003, p. 2.

19 A. R. Jupskås, "The Progress Party: A Fairly Integrated Part of the Norwegian Party System?”, en Karsten Grabow y Florian Hartleb (eds.), Exposing the Demagogues. Right-wing and National Populist Parties in Europe, Bruselas, Konrad Adenauer Stiftung, 2013, p. 206.

${ }^{20}$ P. Ignazi, Extreme Right Parties in Western Europe, Oxford, University Press, 2003, p. 151. 
decreció en los ochenta: mientras el FKP perdió casi todos sus escaños en la Asamblea de Gobierno del Pueblo, el FRP no se consolidó como un actor principal en la Gran Asamblea.

La tercera etapa en Escandinavia se caracterizó por la politización de la inmigración y el chovinismo de bienestar, ${ }^{21}$ ya que el porcentaje de inmigrantes y refugiados se incrementó significativamente en los países nórdicos. ${ }^{22}$ Resultado, éste, de dos factores, uno económico y otro político: por un lado, los nuevos patrones de producción capitalista en la globalización económica incentivaron el arribo de inmigrantes a los mercados más prósperos en Europa Occidental y, por otro, los refugiados expulsados por las guerras étnicas en Yugoslavia y los Balcanes fueron recibidos en estos países garantes de los derechos humanos. En estas circunstancias, la fortuna electoral de los partidos progresistas en Noruega y Dinamarca fue inversamente proporcional: el FRP se convirtió en un partido relevante entre 2001 y 2005, mientras que el FKP decreció hasta perder todos sus escaños en 2001, posición que se acentuó tras la salida de Kjærsgaard en 1995, cuando fundó el Partido Popular Danés (DF) para proteger el Estado de bienestar y combatir la inmigración y las sociedades multiétnicas. ${ }^{23} \mathrm{El}$ DF recolectó los votos del FKP e ingresó al parlamento en 1998, hasta posicionarse hoy día como el segundo partido más votado en Dinamarca. Por su parte, en Suecia, la extrema derecha se reconfiguró, cuando los Demócratas Suecos (SD) irrumpieron en 1988 tras la fusión entre el Partido Sueco y el Partido del Reich

${ }^{21}$ Jens Rydgren, The Populist Challenge: Political Protest and Ethno-nationalist Mobilization in France, Nueva York, Berghahn, 2004, p. 16.

22 T. Bjørklund y J. G. Andersen, "Anti-Immigration Parties in Denmark and Norway: The Progress Parties and the Danish People's Party", en M. Schain et al., (eds.), Shadows over Europe: The Development and Impact of the Extreme Right in Western Europe, Nueva York, Palgrave Macmillan, 2002, p. 110.

${ }^{23}$ E. Bergmann, Nordic Nationalism and Right-Wing Populist Politics: Imperial Relationships and National Sentiments, Londres, Palgrave Macmillan, 2017, pp. 54-55. 
Nórdico. ${ }^{24}$ En un inicio, los padres fundadores de los SD, Leif Zeilon y Anders Klarström, preservaron sus nexos con la escena neonazi, pero con la reestructuración del partido -bajo la gestión de Mikael Jansson- fueron expulsados los grupos supremacistas para legitimarse en la escena política. Sin embargo, este cambio no se reflejó en la votación de 1998. Por último, en Finlandia, Timo Sioni y Raimo Vistbacka refundaron el Partido Rural Finés bajo el nombre de los Auténticos Finlandeses (PS) en 1995. Este partido de raíces agrarias promovió una visión populista sobre la democracia, contrario a las élites y las burocracias, pero también se presentó como el protector del hombre común, ordinario y olvidado, opuesto a la clase corrupta en el poder. ${ }^{25}$ En su primera contienda electoral, los ps no capitalizaron sus propuestas de campaña en contra de la inmigración, el sistema político y la Unión Europea, por lo que no ganaron ninguna curul en la Cámara Baja.

La consolidación del extremismo político en Escandinavia llegó con la cuarta y última etapa. En Dinamarca, el DF respaldó a la coalición de gobierno conducida por los liberales entre 2001 y 2011 y se convirtió en la primera fuerza del "bloque azul" tras los comicios de 2015; en Noruega, el FRP también fue un soporte parlamentario para los democristianos entre 2001 y 2005 y se integró en el gobierno conservador a partir de 2013; por su parte, en Finlandia, los Ps participaron en el gabinete entre 2015 y 2017, pero fueron expulsados de la coalición tripartita por la designación como su presidente de Jussi Halla-aho, personaje vinculado con el neonazismo; por último, en Suecia, los SD superaron el umbral en 2010, incrementaron sus votos en 2014 y se per-

${ }^{24}$ A. M. Klein, "The End of Solidarity? On the Development of Rightwing Populist Parties in Denmark and Sweden”, en K. Grabow y F. Hartleb (eds.), Exposing the Demagogues. Right-wing and National Populist Parties in Europe, Bruselas, Konrad Adenauer Stiftung, 2013, p. 117.

${ }_{25}$ Tapio Raunio, "The Finns: Filling a Gap in the Party System", en ibidem, pp. 133-134. 
filan como uno de los principales protagonistas para los comicios de 2018. ${ }^{26}$

\section{Xenofobia Y GHOVINismo DE BIENESTAR \\ EN EL DISCURSO DE LA EXTREMA DEREGHA}

Durante los ochenta, la extrema derecha populista, en general, y los partidos progresistas nórdicos, en particular, resurgieron en Europa impulsados por un fenómeno propio de la globalización: el crecimiento de los inmigrantes y los refugiados. En esta circunstancia, la xenofobia floreció en defensa de la identidad nacional y las prestaciones sociales, razón por la cual estos partidos modificaron su posición antisistémica por una visión nacionalista. En este sentido, Anders Widfeldt corrobora:

Ni el FkP ni el FrP se centraron en la inmigración en sus primeros diez o quince años. Estos partidos se crearon para combatir la burocracia y los impuestos con sentimientos antisistémicos. Hoy día, sin embargo, la xenofobia y la inmigración son elementos claves para ambos. ${ }^{27}$

$\mathrm{Al}$ respecto, Hans-Georg Betz apunta: "Dentro de la estrategia deslegitimadora de la derecha populista en los noventa, la inmigración y el multiculturalismo asumieron gradualmente una posición central, tanto en términos de mercadotecnia política como de programas políticos". ${ }^{28}$

${ }^{26}$ En septiembre, Electograph publicó las encuestas de YouGov y Sentio Poll con los siguientes resultados: el Partido Socialdemócrata, 26.3 y $25.3 \%$; los Demócratas Suecos, 25.3 y 23.4\%; y Los Moderados, 16 y 17\%. Véase http://www.electograph.com/search/label/Sweden, consultado el 8 de octubre de 2017.

27 "Scandinavia: Mixed Success for the Populist Right", Parliamentary Affairs, vol. 53, núm. 3, 2000, p. 491.

28 Exclusionary Populism in Western Europe in the 1990s and Beyond. A Threat to Democracy and Civil Rights? (Paper 9), United Nations Research 
En los ochenta, el racismo biológico expuesto por el Nazismo mutó en xenofobia cultural. Este cambio se originó, cuando la Nueva Derecha -think tank dirigida por Alain de Benoist- se apartó del Fascismo para reconvertir su aparato ideológico bajo el concepto gramsciano de hegemonía cultu$\mathrm{ral}$, introduciendo una visión etnocéntrica promotora de la diversidad cultural, pero contraria a la supremacía racial. ${ }^{29}$ El racismo diferencialista o racismo cultural, como lo nombran también Pierre-André Taguieff y Michel Wieviorka, respectivamente, no se basa en criterios biológicos ni en jerarquías raciales, sino promociona la idiosincrasia de los pueblos europeos. Este fenómeno ha abandonado el discurso racista para centrarse en la diversidad étnica culturalmente definida. ${ }^{30} \mathrm{~A}$ menudo, este nuevo tipo de racismo se confunde con la xenofobia (hostilidad para con lo extraño), personificada habitualmente por extranjeros (inmigrantes y refugiados), minorías étnicas (gitanos y turcos) y religiosas (judíos y musulmanes) o grupos vulnerables (homosexuales y minusválidos). Enzo Traverso, por su parte, expone: "La xenofobia es un proceso de construcción simbólica del enemigo -inventado como figura negativa- para satisfacer la búsqueda de identidad, el deseo de pertenencia y la necesidad de seguridad y protección". ${ }^{31}$

Ante los crecientes problemas de la inmigración, la multiculturalidad y el terrorismo, Europa cierra sus puertas como castillo medieval con leyes migratorias menos flexibles, programas de repatriación y rígidos controles fronterizos que

Institute for Social Development, Identities, Conflict and Cohesion Programme, 2004, p. 7.

${ }^{29}$ Contrario a la creencia de que la eugenesia fue una política de Estado impulsada por primera vez por la Alemania nazi, Suecia fundó el Instituto Estatal de Biología Racial en 1922, primer centro en el mundo destinado para investigar la "higiene racial".

${ }^{30}$ M. Wieviorka, Le racisme, une introduction, París, La Découverte, 1998, p. 32.

31 "La fábrica del odio. Xenofobia y racismo en Europa", Constelaciones, vol. 4, 2012, p. 411. 
limitan el principio de la libre circulación en el espacio Schengen. ${ }^{32}$ En oposición a la doctrina liberal, la cual concede la ciudadanía según el lugar de nacimiento (ius soli), estos partidos políticos promueven una visión holística, cuya identidad nacional se hereda de generación en generación exclusivamente mediante los padres (ius sanguinis). ${ }^{33}$ Este tipo de nacionalismo, según Roger Eatwell,

se basa por lo regular en una concepción étnica de la nación... El nacionalismo holístico hace hincapié en la conversión o expulsión de los "otros" y defiende el concepto tradicional de comunidad... El rasgo característico socioeconómico de tales partidos radica en la creencia de que los frutos de la economía nacional deben beneficiar prioritariamente a su pueblo («preferencia nacional» en el lenguaje del Frente Nacional). El tema sustancial no sólo radica entre el libre mercado y el estatismo: el debate gira en torno a los intereses de la comunidad original. ${ }^{34}$

Los partidos etnonacionales tienen un sólo propósito: la construcción de una nación homogénea integrada por la totalidad de los nativos. En su concepción, el Estado debe agrupar exclusivamente a la población étnica, la cual se entrelaza por compartir un supuesto origen ancestral, habitar un determinado territorio y poseer una identidad común (la raza, la lengua, la religión, la cultura, los valores y las costumbres). En estas circunstancias, el etnonacionalismo - la simbiosis entre la etnia y la nación- se constituye como el concepto unívoco en la ideología de esta familia política, cuyo signifi-

${ }^{32}$ Entre los Estados que recuperaron el control de sus fronteras en respuesta a la reciente crisis de los refugiados, se encuentran Dinamarca, Noruega, Francia, Suecia, Austria, Alemania y Hungría.

${ }^{33}$ En Europa Occidental predomina el principio del "derecho de sangre", mientras que el "derecho de suelo" prevalece bajo ciertas circunstancias en Francia, Alemania, Grecia, Portugal, España, entre otros países.

34 "The Rebirth of the 'Extreme Right' in Western Europe?", Parliamentary Affairs, vol. 53, núm. 3, 2000, p. 413. 
cado debe entenderse, en palabras de Walker Connor, como "el sentimiento de lealtad hacia la nación". 35

Al respecto, Cas Mudde apunta:

Los partidos nacionalistas aspiran a la congruencia del Estado (unidad política) y la nación (unidad cultural). El Estado debe ejecutar una política de homogeneización interna para crear una sociedad monocultural, la cual, por lo menos, incluya la repatriación de (algunos) extranjeros. Además, la xenofobia determina la visión de los partidos en la que todo lo «anormal» se percibe como negativo y amenazante... La combinación del nacionalismo y la xenofobia condiciona sus políticas socioeconómicas, las cuales son descritas como chovinismo de bienestar, es decir el Estado garantiza el empleo y la asistencia social para beneficio (exclusivo) del propio pueblo. ${ }^{36}$

Por su parte, Jens Rydgren señala:

Mientras que en los ochenta la mayoría de estos partidos compartía una visión neoliberal sobre la economía, en los noventa varios se desplazaron a una posición intermedia defensora del Estado de bienestar. El «chovinismo benefactor» se convirtió en una potente arma retórica para estos partidos, los cuales culpan a los inmigrantes de los males que gravitan sobre este Estado (por ejemplo, bajas pensiones y largas filas en los hospitales). ${ }^{37}$

En los noventa, el extremismo político vinculó exitosamente el paro, la criminalidad, la violencia y la crisis de la beneficencia con los extranjeros en Europa. Sobre este punto, Hans-Georg Betz señala:

35 Ethnonationalism: The Quest for Understanding, Princetown, University Press, 1994, p. xi.

36 The Ideology of the Extreme Right, Manchester, University Press, 2000, p. 177.

37 From Tax Populism to Ethnic Nationalism: Radical Right-Wing Populism in Sweden, Nueva York, Berghahn Books, 2006, p. 11. 
La hostilidad hacia los inmigrantes está motivada por una mezcla de temor y resentimiento que ha surgido en respuesta a las incertidumbres provocadas por la transformación social y cultural de las democracias occidentales avanzadas... Estos temores y resentimientos son el reflejo de que los inmigrantes contribuyen con el paro y el aumento de la violencia y el crimen. Se cree que los extranjeros aprovechan el Rechtsstaat democrático y explotan y abusan del sistema de bienestar social. ${ }^{38}$

En un principio, el discurso xenófobo y excluyente cundió entre los jóvenes, los obreros y los desempleados. Llamados perdedores de la modernidad, estos sectores han sido relegados por la nueva dinámica capitalista en la Europa Occidental. Ellos califican a la inmigración como un fenómeno que desplaza a la juventud sin experiencia laboral, los trabajadores informales (artesanos, campesinos, comerciantes y obreros), pero, sobre todo, para los desempleados, quienes creen que el Estado malgasta los recursos públicos en su beneficio. En la bibliografía se concluye, por lo general, que el voto masculino con bajos niveles educativos y en situación de paro simpatizan mayoritariamente con los partidos de extrema derecha, ${ }^{39}$ puesto que observan en sus propuestas chovinistas un escudo que garantiza el trabajo y la ayuda social para los nativos. Sin embargo, el mercado electoral ha cambiado frente al radicalismo islámico en Europa. El voto para esta familia política se ha diversificado -entre otras razones-, porque los inmigrantes y los refugiados provenientes del Medio Oriente ya no sólo representan un peligro económico, sino también, ahora, perjudican la esfera cultural en Occidente.

Estos partidos aún son votados por un perfil tradicional, pero también los sufragan hoy día las mujeres, los adultos y

38 Radical Right-Wing Populism in Western Europe, Houndmills, Macmillan, 1994, p. 85.

${ }^{39}$ M. Golder, "Far Right Parties in Europe", The Annual Review of Political Science, vol. 19, 2016, p. 483. 
los ancianos con un mejor nivel educativo. ${ }^{40}$ Estos cambios en el perfil del electorado reflejan que el mensaje xenófobo se ha legitimado en la sociedad y los partidos tradicionales. El voto femenino simpatiza con la extrema derecha, porque reprueba la sumisión de las mujeres islámicas, condena las violaciones cometidas por los musulmanes y porque se identifica con el liderazgo de su género (Marine Le Pen, Pia Kjærsgaard, Frauke Petry y Siv Jensen). Los adultos más educados, por su parte, objetan el estilo de vida musulmán, porque contrasta con los valores y las tradiciones de Europa. Los ancianos perciben con recelo, en fin, cómo los recursos del Estado se usan para beneficiar a los inmigrantes, antes que para pagar las pensiones y mejorar los servicios de salud.

\section{LA AGENDA PENDIENTE POR LA SOCIALDEMOCRACIA EN LOS PAÍSES NÓRDICOS}

Últimamente, la desafección política, la crisis económica y el declive cultural han abonado un caldo de cultivo propicio para la inoculación de la xenofobia y el racismo de la extrema derecha en Escandinavia. Ante un contexto de inestabilidad e incertidumbre, la gestión socialdemócrata-encadenada por su tradicional compromiso con la beneficencia, el refugio y los derechos humanos-, ha fracasado en solucionar las peticiones de sus electores, cuyos reclamos se centran en mejorar las prestaciones y los servicios otorgados por el Estado. Según el Eurobarómetro de 2017, los ciudadanos nórdicos exhortan a su gobierno a que enfrente los problemas relacionados con la salud, el paro, la inmigración, entre otros ${ }^{41}$ (véase cuadro 1, de la siguiente página).

${ }^{40}$ Omar García Olascoaga, op. cit., p. 235.

${ }^{41}$ Eurostat, "Eurobarometer Interactive", 2017, en http:/ / ec.europa. $\mathrm{eu} / \mathrm{commfrontoffice/publicopinion/index.cfm/Chart/index,} \mathrm{consulta-}$ do el 18.XII.2017. 


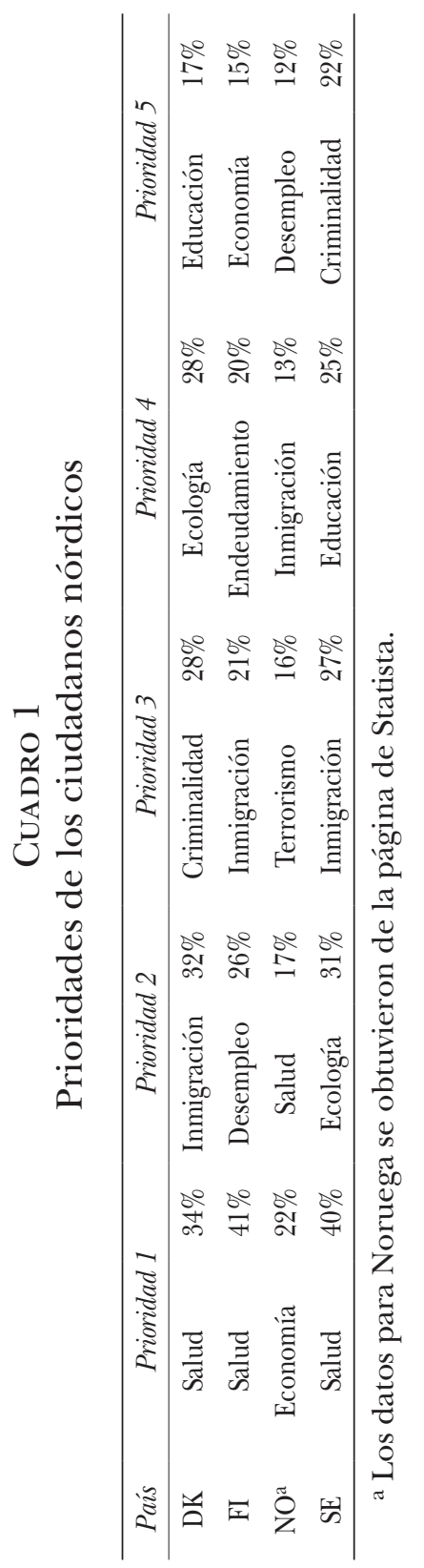


La mayoría de estos problemas tiene su origen en los sesenta, cuando el proceso de descolonización en el África atrajo millones de inmigrantes a Europa. Pero, entre los ochenta y los noventa, Escandinavia recibió una nueva oleada de inmigrantes y refugiados originarios de la Europa del Este -en especial, de los Balcanes y el antiguo bloque soviético-, la cual se ubicó en los países nórdicos por el respeto a los derechos humanos y las prerrogativas del Estado de bienestar. Sin embargo, en la última década, esta situación se ha agudizado a partir de tres eventos: la recesión económica en 2008, la primavera árabe acaecida entre 2010 y 2013, pero, sobre todo, por la crisis de los refugiados en 2015. Tales sucesos han expulsado a millones de personas de su tierra natal con destino a Europa, motivados por la pobreza, la persecución, la guerra y el terrorismo ${ }^{42}$ (véase cuadro 2 , en la siguiente página).

En los ochenta, ante la creciente presencia de inmigrantes y refugiados, la extrema derecha populista elaboró un discurso rentable, en el que vinculó la "invasión extranjera" con el paro laboral, la reducción salarial y la crisis económica: "Dos millones en situación de paro es igual a dos millones de inmigrantes. ¡Demasiados!”, rezaba uno de sus principales axiomas. ${ }^{43}$ Sin embargo, este discurso populista no se perpetuó intactamente y ahora estos partidos políticos no sólo pugnan por la economía, sino también se preocupan por el futuro cultural de Europa. Actualmente, su principal inquietud gira en torno a la composición étnica y la cosmovisión occidental, por lo que respaldan la expulsión de los extranjeros (inmigrantes y refugiados) para preservar intacta la supuesta pureza de los

${ }^{42}$ La Agencia de la onu para los refugiados informó que el total de expatriados en Europa alcanzaba, aproximadamente, los 5.2 millones de personas en 2016. Cf. unHCr, Global Trends. Forced Displacement in 2016, Ginebra, United Nations High Commissioner for Refugees, 2016, en http://www.unhcr.org/statistics/unhcrstats/5943e8a34/global-trendsforced-displacement-2016.html, consultado el 10.X.2017.

43 Durante las euroelecciones de 1984, Jean Marie Le Pen, entonces líder del Frente Nacional, adoptó este rentable eslogan, que le proporcionó por primera vez un número de escaños en el Parlamento Europeo. 
pueblos nativos de Europa. Según el Cline Center for Democracy, la población étnica en el Viejo Continente se ha reducido gradualmente en la era de la globalización económica, sobre todo en aquellas naciones con una visión plural que han abierto recientemente las puertas a los inmigrantes y los refugiados, como Dinamarca, Noruega y Suecia (véase cuadro 3).

\section{Cuadro 2}

Inmigrantes y refugiados

en los países nórdicos entre 1980 y 2015

\begin{tabular}{|c|c|c|c|c|c|c|c|c|c|c|}
\hline \multicolumn{11}{|c|}{ Inmigrantes $^{\mathrm{a}}$} \\
\hline País & \multicolumn{2}{|c|}{1980} & \multicolumn{2}{|c|}{1990} & \multicolumn{2}{|c|}{2000} & \multicolumn{2}{|c|}{2010} & \multicolumn{2}{|c|}{2015} \\
\hline DK & $164 \mathrm{mil}$ & 3.2 & $235 \mathrm{mil}$ & 4.6 & $371 \mathrm{mil}$ & 7 & 510 mil & 9.2 & $573 \mathrm{mil}$ & 10.1 \\
\hline FI & $39 \mathrm{mil}$ & 0.8 & $63 \mathrm{mil}$ & 1.3 & $136 \mathrm{mil}$ & 2.6 & 248 mil & 4.6 & $316 \mathrm{mil}$ & 5.7 \\
\hline NO & $123 \mathrm{mil}$ & 3 & $193 \mathrm{mil}$ & 4.5 & 292 mil & 6.5 & 527 mil & 10.8 & 742 mil & 14.2 \\
\hline SE & $625 \mathrm{mil}$ & 7.5 & $789 \mathrm{mil}$ & 9.2 & $1004 \mathrm{mil}$ & 11.3 & $1385 \mathrm{mil}$ & 14.8 & $1640 \mathrm{mil}$ & 16.8 \\
\hline \multicolumn{11}{|c|}{ Refugiados ${ }^{\mathrm{b}}$} \\
\hline País & \multicolumn{2}{|c|}{1980} & \multicolumn{2}{|c|}{1990} & \multicolumn{2}{|c|}{2000} & \multicolumn{2}{|c|}{2010} & \multicolumn{2}{|l|}{2015} \\
\hline $\mathrm{DK}$ & \multicolumn{2}{|c|}{1800} & \multicolumn{2}{|c|}{32906} & \multicolumn{2}{|c|}{77190} & \multicolumn{2}{|c|}{24501} & \multicolumn{2}{|c|}{36854} \\
\hline FI & \multicolumn{2}{|l|}{0} & \multicolumn{2}{|c|}{2348} & \multicolumn{2}{|c|}{14576} & \multicolumn{2}{|c|}{13946} & \multicolumn{2}{|c|}{39496} \\
\hline NO & \multicolumn{2}{|c|}{$6 \mathrm{mil}$} & \multicolumn{2}{|c|}{19581} & \multicolumn{2}{|c|}{47693} & \multicolumn{2}{|c|}{55851} & \multicolumn{2}{|c|}{78266} \\
\hline SE & \multicolumn{2}{|c|}{$20 \mathrm{mil}$} & \multicolumn{2}{|c|}{109663} & \multicolumn{2}{|c|}{168020} & \multicolumn{2}{|c|}{110608} & \multicolumn{2}{|c|}{357628} \\
\hline
\end{tabular}

a Número de inmigrantes en la población total y respectivos porcentajes. Datos obtenidos del Migration Policy Institute.

b Número de refugiados en la población total. Datos obtenidos del United Nations High Commissioner for Refugees.

\section{Cuadro 3}

Población étnica en los países nórdicos entre 1980 y $2013^{\mathrm{a}}$

\begin{tabular}{lllllllll}
\hline País & 1980 & 1985 & 1990 & 1995 & 2000 & 2005 & 2010 & 2013 \\
\hline DK & 98.2 & 97.7 & 97.2 & 96.1 & 94.9 & 93.4 & 91.5 & 90.2 \\
FI & 93.4 & 93.3 & 93.2 & 93.1 & 93 & 92.9 & 92.7 & 92.7 \\
NO & 97.7 & 97.2 & 96.5 & 95.8 & 94.9 & 93.9 & 92.6 & 91.8 \\
SE & 92 & 91.5 & 90.9 & 90.3 & 89.6 & 89.1 & 88.2 & 87.8 \\
\hline
\end{tabular}

${ }^{\text {a }}$ Como porcentaje de la población total. 
En estas circunstancias, los problemas económicos -la recesión, el paro, la inflación- han dejado de ser el núcleo discursivo de la extrema derecha populista en Europa. Con todo, no hay plena homogeneidad entre los miembros de esta familia política acerca de este punto. Por ejemplo, el FRP siempre ha impulsado políticas de corte neoliberal; por su parte, el DF se pronunciaba, en un inicio, por reducir el papel del Estado sobre la economía, aunque hoy se inclinan, junto con los PS y los SD, por una mayor presencia estatal en este rubro. Por el contrario, estos partidos políticos unifican sus voces y se pronuncian en el mismo sentido respecto a la identidad nacional y la preservación de la civilización en Occidente, es decir priorizan los valores culturales antes que los materiales. Según la Encuesta de Expertos de Chapel Hill, ${ }^{44}$ los partidos populistas de extrema derecha han abandonado gradualmente su posición neoliberal en las últimas décadas para promover un Estado que regule la economía, mientras que los socialdemócratas defienden todavía una visión estatista, pero comienzan a aceptar las reglas del libre mercado; por su parte, los primeros pugnan por comunidades homogéneas, en oposición a los segundos, los cuales apoyan las sociedades multiculturales (véase cuadro 4, de la siguiente página).

En el siglo que corre, el discurso de la extrema derecha se ha reorientado para extender su base electoral. Ahora ya no rechaza a una inmigración en general, sino a una en particular: los creyentes del Islam. Después del atentado terrorista de 2004 en Madrid, España, estos partidos políticos han culpado a los musulmanes de la inseguridad, la criminalidad y la decadencia en Occidente e insisten que la "invasión extranjera" procedente del mundo islámico condiciona el futuro del pueblo nórdico, puesto que -en su visión etnocéntrica-, la civilización cristiana es incompatible con el Corán. Desde entonces, los grupos islamófobos han brotado por toda Escandinavia: el Movimiento de Resistencia Nórdico, la Liga de la

44 Jonathan Polk et. al., Chapel Hill Expert Survey (CHES) 1999-2014, 2015, en http://ches.web.unc.edu/, consultado el 12.X.2017. 
Defensa Europea, los Patriotas Europeos contra la islamización de Occidente y los Soldados de Odín. Según los pronósticos del Pew Research Center, la religión islámica aumentará en las próximas décadas en el Viejo Continente de forma inversa proporcionalmente a la religión cristiana. En los países nórdicos, la presencia de los feligreses de Alá crecerá paulatinamente en Finlandia, Dinamarca y Noruega, pero aún más en el caso de Suecia (véase cuadro 5).

\section{CUADro 4}

Posición de la extrema derecha

sobre la economía y la cultura entre 1999 y $2014^{\mathrm{a}}$

\begin{tabular}{|l|c|c|c|c|c|c|c|c|c|c|}
\hline Partido & \multicolumn{2}{|c|}{1999} & \multicolumn{2}{c|}{2002} & \multicolumn{2}{c|}{2006} & \multicolumn{2}{c|}{2010} & \multicolumn{2}{c|}{2014} \\
\hline & E & C & E & C & E & C & E & C & E & C \\
DF & 7.3 & - & 6.1 & - & 4.8 & 9.6 & 5.5 & 9.5 & 4.5 & 9.5 \\
SD & 3.4 & - & 3.7 & - & 3.6 & 6.6 & 3.8 & 6.2 & 3.9 & 5.4 \\
PS & 5.4 & - & - & - & 4.8 & 7.9 & 4.3 & 9.1 & 4.1 & 9.4 \\
SDP & 3.4 & - & - & - & 3 & 5.1 & 3.6 & 5.6 & 3.4 & 4 \\
FRP & - & - & - & - & - & - & 7.7 & 9.3 & 7.5 & 8.7 \\
DNA & - & - & - & - & - & - & 3.7 & 4.4 & 3.8 & 4.7 \\
SD & - & - & - & - & - & - & 5.5 & 9.8 & 5.4 & 9.8 \\
SAP & - & - & - & - & - & - & 3.4 & 2.8 & 3.4 & 2.3 \\
\hline
\end{tabular}

a $\mathrm{E}=$ Posición respecto a la economía: estatista (1) y libre mercado (10). C = Posición sobre la cultura: multicultural (1) e integración (10).

La islamofobia se convirtió en un recurso de exclusión rentable para el extremismo nórdico. En este clima de intolerancia religiosa, Pia Kjærsgaard, la otrora lideresa del DF, introdujo en el lenguaje cotidiano frases como "lo no danés", "daneses étnicos" o "inmigrantes de segunda y tercera generación”. En la campaña de 2001, el DF presentó un cartel en que exhibió a una joven rubia con el mensaje: "Cuando ella se retire, Dinamarca tendrá una mayoría musulmana”. Por su parte, el FRP repartió en los comicios de 2005 un folleto con los rostros de un par de jóvenes musulmanes con la leyenda: "El criminal es de origen extranjero". Después de los actos 
terroristas en la isla de Utøya en 2011, Siv Jensen, la presidente del FRP, expresó: "Los ataques cometidos por Anders Breivik no deben ocultar la persistente amenaza islámica”. A su vez, Jussi Halla-aho, líder de los Ps, quien está relacionado con Breivik, escribió en 2008: "El islam es una religión pedófila”. Los ps promueven que la asistencia social y la salubridad se otorguen sólo a los nativos. Por último, Jimmie Åkesson, presidente de los SD, ha señalado: "El islamismo es el nazismo y el comunismo de nuestro tiempo". En las elecciones de 2010, los SD lanzaron un anuncio en el que una mujer nativa de la tercera edad no recibía a tiempo los recursos del Estado, que rezaba: "Puedes elegir si quieres proteger el dinero para las pensiones o el presupuesto para la inmigración".

\section{CUADro 5}

Proyección de la religión en Europa

y los países nórdicos entre 2010 y $2050^{\mathrm{a}}$

\begin{tabular}{|l|c|c|c|c|c|c|c|c|}
\hline País & Año & Cristianos & Musulmanes & Hindús & Budistas & Judios & Apóstatas & Otros \\
\hline \multirow{3}{*}{ Europa } & 2010 & 74.5 & 5.9 & 0.2 & 0.2 & 0.2 & 18.8 & 0.2 \\
& 2050 & 65.2 & 10.2 & 0.4 & 0.4 & 0.2 & 23.3 & 0.4 \\
DK & 2010 & 83.5 & 4.1 & 0.4 & 0.2 & 0.1 & 11.8 & 0.2 \\
& 2050 & 78.6 & 8.5 & 0.9 & 0.8 & 0.1 & 11 & 0.3 \\
FI & 2010 & 80.1 & 0.8 & 0.1 & 0.1 & 0.1 & 19.1 & 0.2 \\
& 2050 & 72.5 & 3.4 & 0.2 & 0.4 & 0.1 & 23.2 & 0.2 \\
NO & 2010 & 84.7 & 3.7 & 0.5 & 0.6 & 0.2 & 10.1 & 0.3 \\
& 2050 & 73.7 & 8.9 & 0.9 & 1.5 & 0.2 & 14.5 & 0.4 \\
SE & 2010 & 67.2 & 4.6 & 0.2 & 0.4 & 0.1 & 27 & 0.4 \\
& 2050 & 52.3 & 12.4 & 0.5 & 1.2 & 0.2 & 32.8 & 0.8 \\
\hline
\end{tabular}

a Como porcentaje de la población total.

Los atentados terroristas atribuidos al Estado Islámico han detonado la xenofobia en contra de los musulmanes. Desde 2004, el Viejo Continente se ha convertido en el escenario predilecto del terrorismo islámico a raíz de los ataques perpetrados por la OTAN para exterminar a los grupos yiha- 
distas ubicados en Siria e Irak, pero, sobre todo, por las caricaturas irreverentes publicadas por la prensa occidental. Ciudades como Madrid, Londres, París, Copenhague, Bruselas, Berlín, Estocolmo, entre otras, han sido el objetivo de los simpatizantes de Alá. Desde entonces, Europa no pernocta como en el pasado, porque vive con miedo e incertidumbre, situación que ha legitimado el discurso retórico xenófobo del extremismo político entre los ciudadanos, pero particularmente ha propiciado un clima de intolerancia religiosa entre los europeos católicos y los musulmanes islámicos.

En 2005, inició esta cruzada religiosa, cuando un rotativo danés publicó una serie de caricaturas satíricas en contra del Islam, reproducidas luego por la prensa escandinava. En venganza, en 2006, el fundamentalismo islámico incendió las embajadas nórdicas en Damasco, Siria, e hizo estallar un coche bomba en contra de la legación danesa en Islamabad, Pakistán, en 2008. La respuesta del extremismo político fue contundente. En 2011, Anders Breivik, partidario neonazi y otrora militante del FRP, asesinó a 77 personas (entre burócratas y jóvenes del Partido Laborista), motivado por la "invasión islámica" y el multiculturalismo en Noruega. Recientemente, el Estado Islámico reconoció los atentados en Copenhague y Estocolmo en 2015 y 2017, respectivamente. Por su parte, Suecia ha sido nombrada como "la capital de las violaciones en Occidente", ya que con la recepción de la cuota de refugiados se incrementaron las agresiones sexuales en contra de las mujeres nórdicas. En un inicio, la correlación entre violaciones y refugiados no fue reconocida por el gobierno socialdemócrata, pero la ministra de Integración, Ylva Johansson, aceptó que estos ilícitos crecían proporcionalmente a la presencia de extranjeros de origen musulmán, lo cual motivó la cancelación de un festival de música tras repetirse estos agravios en 2017. 
LA CAÍDA DE LA SOCIALDEMOCRACIA

Y LA ASCENSIÓN DEL EXTREMISMO POLÍTICO

Durante casi todo el siglo xx, la socialdemocracia gobernó como el partido predominante en los regímenes democráticos nórdicos. ${ }^{45}$ Esta posición en el tablero político fue resultado del Estado de bienestar proveedor de una extensa red de prerrogativas en materia de salud, educación, vivienda, pensiones. Sin embargo, la crisis de la izquierda se originó en los noventa, cuando el Comunismo hizo crisis, etapa en la cual la socialdemocracia enfrentó una disyuntiva, es decir extenderse hacia la izquierda para recolectar el voto obrero con una visión estatista o recorrerse hacia el centro para obtener posiciones en el gobierno con tintes neoliberales. Los socialdemócratas se inclinaron por esta última opción. La izquierda, con esta decisión, abandonó definitivamente el voto proletario, el cual se refugió en los partidos nacionalistas -promotores de la beneficencia exclusiva para los nativos-, cuyos integrantes han sido calificados irónicamente por Ove K. Pedersen como "la extrema derecha socialdemócrata".

A la inversa de lo que sucede en el resto de Europa, estos partidos han cooperado con el gobierno en turno con el propósito de ser reconocidos y legitimados como un integrante más en la escena política. En este sentido, la purga neonazi, el relevo generacional y la inoculación de sus propuestas de campaña son las principales razones que explican su crecimiento electoral y estabilidad política. Asimismo, lejos de apartarlos de la vida institucional por medio de inoperantes cordones sanitarios como sucede en Bélgica, Francia y el Reino Unido, los partidos tradicionales -principalmente los ubicados a la derecha- han concretado coaliciones de gobierno con ellos en perjuicio de la izquierda.

Desde sus orígenes, el DF asumió un papel destacado en el gobierno de Dinamarca y se convirtió, en la práctica, en un

${ }^{45}$ Véase T. J. Pempel (ed.), Uncommon Democracies: The One Party Dominant Regimes, Nueva York, Cornell University Press, 1990. 
intermediario entre los progresistas de centro-izquierda y los conservadores de centro-derecha. Desde la expulsión de los radicales en 1995, el partido de Pia Kjærsgaard ha crecido en las urnas, posición que le permite influir en el sistema político. El DF rechaza categóricamente la inmigración islámica por su incompatibilidad con la cultura y las tradiciones de la comunidad nativa. La extrema derecha populista tuvo éxito en la transformación radical de las políticas migratorias como un partido de apoyo para el gobierno de coalición liberalconservador entre 2001 y $2011 .{ }^{46}$ En este periodo, el DF no sólo negoció una ley migratoria más restrictiva, sino también promovió medidas para endurecer el Estado de derecho y prevenir el abuso del Estado de bienestar. ${ }^{47}$ Por ejemplo, Kjærsgaard presentó una iniciativa de ley en 2009, en la que ofreció un pago único a todos aquellos inmigrantes no occidentales que renunciaran a su residencia y retornaran a su país de origen. En su óptica, el Estado se ahorraría importantes recursos a la larga, puesto que ya no representarían más un gasto en materia social. Asimismo, el DF argumentó que con esta propuesta se reduciría la criminalidad, se protegería la identidad nacional y se preservaría la homogeneidad del pueblo danés.

Después de la gestión socialdemócrata entre 2011 y 2015 , la coalición conservadora recuperó las riendas del poder en Dinamarca e invitó a la extrema derecha a incorporarse a su gobierno. Sin embargo, el DF nuevamente rechazó la oferta, ya que, según sus cálculos, influye más en el Ejecutivo desde una posición paralela, pero sin el desgaste que conlleva el ejercicio del poder. En estos comicios, los otrora votantes de

${ }^{46}$ A. C. Jungar, "Populism in the Nordic Countries: New Voices, Old Roots", en H. Giusto et al. (eds.), The Changing Faces of Populism, Bruselas, Foundation for European Progressive Studies, 2013, p. 262.

${ }^{47}$ S. Meret, "From the Margins to the Mainstream? The Development of the Radical Right in Denmark", en N. Langenbacher y B. Schellenberg (eds.), Is Europe on the "Right» Path? Right-Wing Extremism and Right-Wing Populism in Europe, Berlín, Friedrich Ebert Stiftung-Forum Berlin-Project Combating Right-wing Extremism, 2011, p. 251. 
la izquierda simpatizaron con las propuestas nacionalistas centradas en la protección de los sectores más vulnerables: ancianos, enfermos, desempleados y obreros. En 2015, el DF presentó un nuevo proyecto de ley antiinmigrante para encarar la crisis de los refugiados, el cual fue aprobado por sus socios de gobierno, pero también -contra toda lógica-contó con el respaldo socialdemócrata. De entre los puntos más controvertidos, descuellan la confiscación de dinero y joyas a la inmigración ilegal, el emplazo para la reunificación familiar de los refugiados y el recorte del bono económico para los inmigrantes. Con todo, se incentivaron las políticas de asimilación cultural, recompensando a todos los extranjeros que aprendiesen el idioma natal y se enrolasen en un trabajo formal para pagar impuestos.

Por su parte, el FRP ha transitado por tres etapas: la postura antisistémica, la oposición responsable y la participación en el gobierno. Entre 1985 y 2001, el FRP mantuvo el equilibrio del poder entre los bloques de izquierda y derecha, posición que lo legitimó en la política noruega. ${ }^{48}$ Aunque en esta época los liberales y los radicales ganaron un mayor número de espacios en el partido, el entonces presidente, Carl I. Hagen, neutralizó esta situación con la salida de los progresistas en 1994 y la expulsión del ala más extrema en 2001. Con estas medidas, el partido se inclinó hacia el centro para ser más influyente en la toma de decisiones del gobierno, pero sin renunciar a la bandera antinmigrante y el chovinismo de bienestar. A pesar de su evidente xenofobia, el FRP no se reconoce como un integrante más de la extrema derecha populista y niega todo vínculo con esta familia política, razón por la cual preserva una imagen "socialmente respetable" y se aparta explícitamente del racismo. ${ }^{49}$ Sin embargo, lo cierto

48 A. Widfeldt, Extreme Right Parties in Scandinavia, Londres, Routledge, 2015, p. 90 .

49 Tor Bjørklund, "The Radical Right in Norway: The Development of the Progress Party", en N. Langenbacher y B. Schellenberg (eds.), Is Europe on the "Right» Path? Right-Wing Extremism and Right-Wing Populism in 
es que su ofensiva se ha centrado en contra de la inmigración islámica y la comunidad lapona del norte de Escandinavia.

El FRP fue un actor indispensable tras los comicios de 2001, cuando respaldó la integración del gobierno de minoría conducido por los democristianos. Sin embargo, en 2005, el partido liderado por Hagen retiró su apoyo parlamentario por no ser incluido en las negociaciones de una coalición de centro-derecha, a pesar de su porcentaje de votos. Este aislamiento terminó en 2013, cuando el Partido Conservador por fin invitó al FRP a un gobierno de coalición. Desde esta posición, los progresistas han emulado la política de repatriación del DF, por lo que impulsan un programa voluntario para la inmigración ilegal, si deciden regresar a su patria. En 2015, el FRP presentó reformas a la ley de Asilo para contener la ola de refugiados originaria del Medio Oriente, respaldada por casi todos los partidos, con excepción de los verdes y los socialistas. Asimismo, poco antes de los comicios de 2017, la coalición conservadora ratificó una ley que prohíbe el uso del velo facial en las escuelas públicas, convirtiendo a Noruega en la primera nación nórdica en adoptar esta medida en contra de la comunidad musulmana.

En Finlandia, el Partido Rural Finlandés se refundó en 1995 para crear a los PS. En un inicio, su escasa presencia en la casa de los Representantes del Pueblo no le permitió influir en la política nacional, sin embargo ha cobrado cierta relevancia últimamente y se ha integrado a una coalición de gobierno. Este partido divide su propuesta en tres ejes: la defensa del pueblo, el euroescepticismo y el etnonacionalismo. ${ }^{50}$ Desde sus orígenes, los Ps se han inclinado por ser un partido populista a favor de los pobres, pero opuesto a la élite política corrupta. Los populistas se reconocen nacionalistas y socialcristianos, pero critican la presencia del Islam, sobre todo tras la anexión de los radicales a sus filas. Después

Europe, Berlín, Friedrich Ebert Stiftung-Forum Berlin-Project Combating Right-wing Extremism, 2011, p. 286.

50 Tapio Raunio, art. cit., p. 138. 
de 2007, los Ps -como en el resto de Escandinavia- incorporaron el chovinismo de bienestar para beneficiar a los nativos respecto al trabajo y las ayudas sociales. ${ }^{51}$

La irrupción de los Ps en la escena política llegó con los comicios de 2011, cuando ocupó el tercer puesto en el sistema de partidos. Estas elecciones marcaron el final de una época conocida como la "política de consenso", la cual, hasta ese entonces, fue monopolizada por tres fuerzas políticas: los partidos Socialdemócrata, del Centro y de la Coalición Nacional. A pesar de su exponencial crecimiento electoral en 2011, los populistas no participaron en la coalición de gobierno, pues permanecieron en la oposición. Su ingreso llegó tras los comicios de 2015, posición desde la que aprobó una ley migratoria más restrictiva para contener la ola de refugiados e inhibir las solicitudes de asilo político. Empero, estos cambios fueron reprobados por Jussi Halla-aho, ideólogo de los Ps y de tendencias neonazis, quien criticó la condescendencia de su partido en el gobierno para perfilarse como su nuevo líder. El relevo en la cúpula partidista propició una crisis de gobierno entre los partidos de centro-derecha y la extrema derecha, cuyo destino fue la división de los Ps en dos grupos antagónicos: los moderados, guiados por el propio Soini, y los radicales, dirigidos por Halla-aho.

En estos tres países, los socialdemócratas han retrocedido electoralmente a favor de los partidos etnonacionalistas. Diseñada por una visión chovinista, la plataforma electoral de la extrema derecha ahora es votada por los antiguos simpatizantes de la izquierda tradicional, quienes los reconocen como los legítimos portavoces de las causas populares. En las últimas citas electorales en Escandinavia, resulta evidente observar cómo los votos perdidos por la socialdemocracia han sido captados por esta familia política (véase gráfica 1, en la siguiente página). Actualmente, Suecia ha permanecido inmune a la presencia de los etnonacionalistas en un gobierno de coalición. Sin embargo, la participación de los SD sólo parece

${ }^{51}$ Ann-Cathrine Jungar, art. cit., p. 263. 
ser cuestión de tiempo, particularmente en un escenario en el que las encuestas no vaticinan mayorías en el parlamento para ninguno de los dos bloques: el Roji-Verde (centro-izquierda) y la Alianza (centro-derecha). En estas circunstancias, Ulf Kristersson, líder de Los Moderados, declaró recientemente: "No tengo la intención de excluir a ningún partido... Estoy preparado para negociar y crear un amplio acuerdo parlamentario sobre una mejor política de refugiados". ${ }^{52}$

\section{GRÁFICA 1}

La caída socialdemócrata y la ascensión etnonacionalista

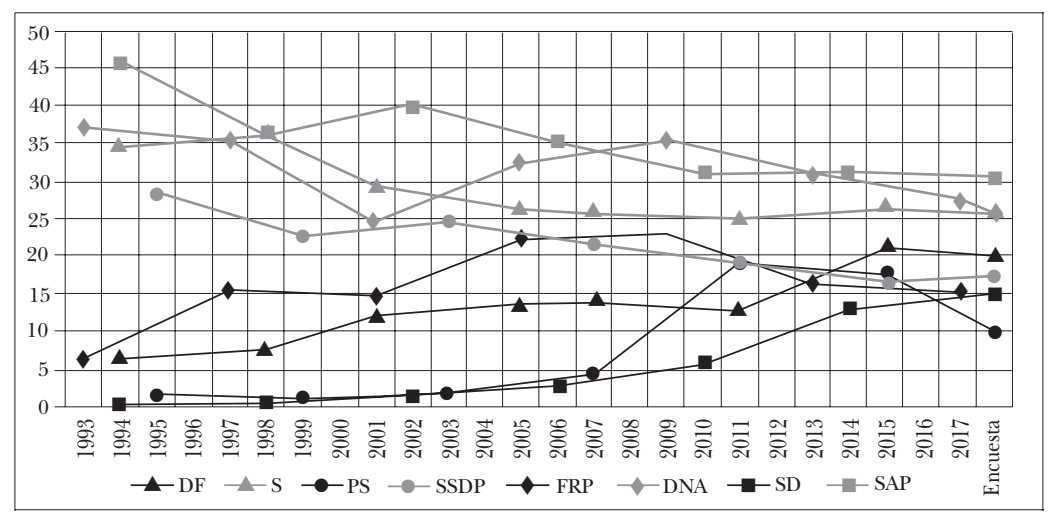

Fuente: Elaboración propia con resultados electorales de los partidos etnonacionalistas (negro) y los socialdemócratas (gris).

Hacia 1994, en Dinamarca, se recuperó el voto del Partido del Progreso (antecesor del DF), mientras que hacia 1995, en Finlandia, se recogió la votación del Partido Rural (precedente de los PS). Los porcentajes de las encuestas para octubre se obtuvieron en Voxmeter (Dinamarca), Taloustutkimus (Finlandia), Opinion (Noruega) y Kanar sifo (Suecia).

52 “Sweden's Moderates open to Sweden Democrats immigration deal", The Local, 7 de mayo de 2018, en https: / / www.thelocal.se/20180507 / swedens-moderates-open-to-sweden-democrats-immigration-deal, consultado el 12.V.2018. 


\section{Los Demócratas Suecos}

EN EL ÚLTIMO BASTIÓN SOCIALDEMÓCRATA

Suecia es el único país nórdico que todavía no permite el ingreso de la extrema derecha populista como parte de un gobierno de coalición. Sin embargo, la incorporación de los SD en el Parlamento tras los comicios en 2010, su avance electoral en 2014, pero, en especial, la preferencia con miras a la contienda de 2018, los ubican en una posición sin precedentes en su búsqueda por el poder político. La ascensión de los SD simboliza un retroceso para la democracia en general, pero, sobre todo, para la socialdemocracia en particular, puesto que los principios de la justicia social y la solidaridad comienzan a reemplazarse con una visión excluyente que se contrapone a la tolerancia, la pluralidad y la igualdad. En casi todo el siglo xx, el Partido Socialdemócrata gobernó como un partido predominante en Suecia, aunque sus votos hayan decrecido últimamente hasta ubicarse en los niveles más bajos en toda su historia, posición desde la que negoció, por primera vez, una coalición de gobierno con Los Verdes.

El antecesor inmediato de los SD fue el Partido Sueco (SP), en el cual coincidieron varios miembros del Partido del Progreso y la organización neonazi Preservar a Suecia Sueca en 1986. Sin embargo, a causa de la mala imagen en los medios por su radicalismo en las calles y los problemas en la cúpula por el control de partido, el sP se refundó en los SD en 1988. Este partido nacionalista, por tanto, tiene sus raíces en el fascismo sueco en una época -entre finales de los ochenta e inicios de los noventa- en la cual concurrieron una variedad de grupos abiertamente antidemocráticos, nazis y fascistas. 53

En este clima radical, Olof Palme, primer ministro sueco e insignia socialdemócrata por su influencia internacional,

${ }^{53}$ Apud J. Rydgren y P. Ruth, "Voting for the Radical Right in Swedish Municipalities: Social Marginality and Ethnic Competition?", Scandinavian Political Studies, vol. 34, núm. 3, 2011, p. 205. 
fue asesinado presuntamente por sectores de la ultraderecha. Con el tiempo, sin embargo, surgieron una serie de teorías conspiratorias que involucraron a los adeptos del régimen del apartheid en Sudáfrica, la dictadura chilena de Augusto Pinochet, los servicios secretos de la cia y el gobierno británico, el Mossad israelí, los simpatizantes del Partido de los Trabajadores del Kurdistán, la Fracción del Ejército Rojo alemana, los extremistas croatas de la Ustacha, entre otros. Lo cierto es, con todo, que el magnicidio de Palme todavía no se ha resuelto y, a pesar de haber prescripto en 2011, el gobierno sueco ha decidido reabrir la investigación para esclarecerla ante la opinión pública.

Este hecho condenó la escena neonazi en Suecia, la cual, sin embargo, se reconstruyó con el paso del tiempo. En sus inicios, bajo la presidencia de Anders Klarström (1992-1995), otrora militante del Partido del Reich Nórdico, los SD fueron un partido marginal a causa de sus vínculos con el Neonazismo, las protestas callejeras y su posición antisistémica. Este inconveniente se resolvió pronto. En el mandato de Mikael Jansson (1995-2005), la cúpula partidista cortó con su pasado: se excluyó a los skinheads, se erradicó el antisemitismo y se censuró toda apología sobre la raza nórdica. ${ }^{54}$ Apartados de esta herencia, los SD sustituyeron el racismo biológico por el etnocentrismo cultural, cambios que motivaron un éxodo en 2001, cuando la militancia más radical abandonó sus filas para crear el partido Demócratas Nacionales, el cual, pese a todo, se desintegró en 2014.

En 2003, en la víspera del referendum para adoptar el euro en Suecia, Anna Lindh, Ministra de Asuntos Exteriores y promotora de la moneda única, fue víctima de un atentado cometido por Mijailo Mijailović, de origen serbio, quien confesó que su crimen fue motivado por las operaciones militares de la OTAN en contra de su patria en 1999, las cuales fueron jus-

${ }^{54}$ En 1999, Björn Söderberg, sindicalista y activista, fue asesinado a las puertas de su casa por tres jóvenes neonazis pertenecientes a la organización Juventud Nacional. 
tificadas por la funcionaria. Sin embargo, el magnicidio no fue resuelto con toda claridad (como en el caso de Palme), ya que se presume que Mijailović actuó en complicidad con Per Olof Svensson, primer detenido y vinculado con los círculos neonazis suecos, para consumar el homicidio de Lindh.

$\mathrm{Al}$ alborear el siglo XxI, los SD no eran más que un partido marginal que no representaba un peligro para la vida liberal y democrática en Suecia, ni para los gobiernos liderados por los partidos tradicionales. Incluso, en 2002, el investigador Jens Rydgren había sentenciado que el populismo de derecha era un fracaso en este país, aunque se cuestionara por cuánto tiempo más. ${ }^{55}$ Sólo bastó con poco menos de una década para que una de las sociedades más prósperas, avanzadas y tolerantes en el mundo fuera seducida por la plataforma xenófoba y racista expuesta por este partido político.

El punto de inflexión para los SD llegó con la presidencia de Jimmie Åkesson (de 2005 al presente), quien de inmediato prohibió toda apología neonazi y racista. Desde entonces, el partido ha moderado su discurso, pero sin evadir su papel como protector de los valores y las costumbres de los nativos suecos: "La nación se define en términos comunes de lealtad, identidad, lengua y cultura". ${ }^{56}$ Durante su mandato, los SD han progresado y en cada elección han duplicado sus votos: $2.9 \%(2006), 5.7 \%(2010)$ y $12.9 \%$ (2014). En una reciente encuesta, los SD $(22.4 \%)$ están ligeramente por encima de Los Moderados (18.8\%) y a poco menos de dos puntos del Partido Socialdemócrata (24\%). ${ }^{57}$

Ante la creciente ola de inmigrantes islámicos, el partido dirigido por Åkesson ha apuntalado su discurso xenófobo: "El Islam se ha convertido en la peor amenaza para Suecia

55 Véase J. Rydgren, "Radical Right Populism in Sweden: Still a Failure, But for How Long?”, Scandinavian Political Studies, vol. 25, núm. 1, 2002, pp. 27-56.

56 Sverigedemokraterna, Principprogram, 2011, p. 15.

57 Electograph, Sweden YouGov Poll, 2018, en https://www.electograph.com/2018/03/sweden-yougov-poll-for-metro-march-2018.html, consultado el 12.V.2018. 
desde la Segunda Guerra Mundial”. La entrada en el parlamento de los SD en 2010 fue muy significativa, ya que simbolizó el final del Folkhemmet ('el hogar del pueblo'), ${ }^{58}$ la insignia socialdemócrata cuyo sentido ha sido redefinido por los etnonacionalistas como el espacio donde deben habitar exclusivamente los nativos suecos. A pesar de la purga de los neonazis y la política de "cero tolerancia", la militancia de los SD se ha expresado sin ninguna restricción: "Los negros nunca han evolucionado" (Per T. K. Wahlberg); "estoy en contra de la mezcla de razas" (Isak Nygren); "el Islam debe prohibirse en Suecia” (Pär Norling); "los inmigrantes poseen un coeficiente intelectual menor que el de los suecos" (Stellan Bojerud); "todos los inmigrantes son parásitos" (Jonas Åkerlund); "hay que recurrir a las armas para salvar a la raza blanca" (Kent Ekeroth); "la etnicidad incluye elementos como la cultura, el idioma y la religión, pero sin ignorar el hecho de que la apariencia también tiene un significado" (Jimmie Åkesson). ${ }^{59} \mathrm{El}$ año pasado, Martin Strid, partidario de los SD, fue expulsado del partido por aseverar que "los musulmanes no son completamente humanos".

Este discurso de exclusión racial e intolerancia religiosa se ha legitimado en el parlamento sueco. Recientemente, la coalición de gobierno "rojiverde" (socialdemócratas y ecologistas) aprobó una ley sobre la política de asilo, vigente para el periodo 2016-2019, la cual contó con los votos opositores (conservadores y etnonacionalistas). Entre sus principales puntos se encuentran reemplazar los permisos de residencia permanentes por temporales, restringir la reagrupación familiar de los inmigrantes y recortar las ayudas económicas. Inmerso en este clima xenófobo, justo en el momento más bajo de su popularidad entre los electores, el Partido Socialdemócrata enfrenta una encrucijada: continuar con la adop-

${ }^{58}$ Concepto acuñado por la socialdemocracia para representar el Estado multicultural de oportunidades para todos los individuos.

${ }^{59}$ D. Vergara, "Rasismen i SD riksdagsgrupp", Expo, 12 de septiembre de 2014, en http://expo.se/2014/rasismen-i-sds-riksdagsgrupp_6635. html, consultado el 30.X.2017. 
ción de propuestas ajenas a su ideología para contener el avance de los SD o retroceder y recuperar su tradicional política de "puertas abiertas", pese a que ello represente un peligro para la preservación del Estado de bienestar y la identidad nacional en Suecia.

\section{Conclusiones}

En este punto del siglo que corre, Escandinavia ha sido alcanzada por el extremismo político de corte nacionalista, populista, xenófobo y racista, a pesar de que en aquella región del norte de Europa parecía inconcebible hasta hace poco su presencia por el crecimiento económico, los estándares de vida y la tradicional política de tolerancia y pluralismo para con los extranjeros. Pero todo cambió radicalmente en las últimas décadas. Actualmente, ninguna democracia nórdica ha permanecido inmune a la xenofobia y el racismo expuestos por los integrantes de esta familia política, la cual ha ganado gradualmente mayor presencia e influencia en la esfera de gobierno. Este fenómeno ha trascendido el ámbito de lo político y ha incidido en el comportamiento de la sociedad por medio de prácticas de exclusión como la discriminación y el odio racial, perpetrados principalmente por grupúsculos extremistas -nostálgicos neonazis y supremacistas blancos-, precisamente en la región donde paradójicamente se otorgan año tras año los premios Nobel.

En los últimos años, bajo la influencia de estos partidos políticos nacionalistas -hostiles a los inmigrantes, los refugiados, el islamismo y el multiculturalismo-, los gobiernos en Dinamarca, Finlandia, Noruega y Suecia -integrados principalmente por los socialdemócratas, los conservadores y los liberales- han recortado cada vez más los servicios estatales y las prestaciones sociales para los recién llegados y aprobado leyes migratorias mucho más restrictivas para evitar su llegada, a pesar de contravenir los principios y los valores fundamentales de la Unión Europea. 
Iniciada la Posguerra, los partidos socialdemócratas en el Viejo Continente impulsaron un modelo económico exitoso, garante de la prosperidad y el progreso: el Estado de bienestar. Sin embargo, la bonanza económica en Escandinavia -como en el resto de Europa- entró en un periodo de incertidumbre e inestabilidad con la ruptura del sistema patrón oro y la crisis del petróleo a principios de los setenta. En vísperas de la globalización, la reestructuración del modo de producción capitalista demandó la mano de obra de los inmigrantes para garantizar la continuidad respecto a las prerrogativas otorgadas por el Estado. Este panorama representó una oportunidad única para los extranjeros, quienes vislumbraron en esos lares la Tierra Prometida, donde habrían de mejorar sus condiciones de vida.

En estas circunstancias, Europa acogió a millones de extranjeros provenientes de su periferia tras el proceso de descolonización del África, la ulterior desintegración del régimen soviético y las posteriores guerras nativistas en la región balcánica. Los cambios sociodemográficos suscitados a raíz de estos hechos repercutieron en la aparición de un conjunto de problemas que la socialdemocracia no ha solucionado oportunamente, como el paro, la inmigración, la salubridad y el terrorismo, los cuales, entre otros, se han agravado a partir de la recesión económica en 2008, la primavera árabe entre 2010 y 2013, pero, sobre todo, por la reciente crisis de los refugiados, iniciada en 2015.

Escandinavia enfrenta un ambiente intoxicado por el discurso de exclusión, cuyos objetivos son, por un lado, la supresión de la visión progresista de la socialdemocracia y, por otro, la expulsión inmediata de los inmigrantes islámicos, quienes representan un peligro para la preservación de los valores, las tradiciones y las costumbres, así como para su identidad como grupo étnico originario de las tierras ancestrales en Europa. Dos visiones se contraponen entre la socialdemocracia y el etnonacionalismo, las cuales no se han reconciliado entre sí: sociedad-comunidad, extranjeros-nativos, inclusión-exclusión, heterogeneidad-homogeneidad, asimilación-identidad, mul- 
ticulturalismo-etnocentrismo, individualismo-colectivismo y liberalismo-nacionalismo.

Desde hace décadas, los partidos de extrema derecha, que transitaron de una posición antisistémica a una oposición responsable, han ingresado por la puerta principal en los parlamentos nórdicos, respetando las reglas democráticas, pero también legitimando sus propuestas entre los ciudadanos y los partidos tradicionales. En este siglo, sus curules se han convertido en una mayor participación en los gobiernos de coalición en Dinamarca, Finlandia y Noruega. Por su parte, Suecia, el último reducto socialdemócrata, ha resistido momentáneamente el embate de la extrema derecha populista, cuyo objetivo consiste en ejercer el poder como primera fuerza. Con todo, parece ser cuestión de tiempo para que las voces nacionalistas, animadas por el recuerdo del último "Rey Guerrero", Carlos XII, retumben en las oficinas gubernamentales del Palacio de Rosenbad.

\section{Bibliografía}

Andersen, Jørgen G., The Danish People's Party and New Cleavages in Danish Politics, Aalborg, Aalborg Universitet, 2003.

Backes, Uwe, Political Extremes. A Conceptual History from Antiquity to the Present, Londres, Routledge, 2011.

y Jesse Eckhard (eds.), Vergleichende Extremismusforschung, Baden-Baden, Nomos, 2005.

Bergmann, Eirikur, Nordic Nationalism and Right-Wing Populist Politics: Imperial Relationships and National Sentiments, Londres, Palgrave Macmillan, 2017.

Betz, Hans-Georg, Radical Right-Wing Populism in Western Europe, Houndmills, Macmillan, 1994.

, Exclusionary Populism in Western Europe in the 1990s and Beyond. A Threat to Democracy and Civil Rights? (Paper 9), United Nations Research Institute for Social Development, Identities, Conflict and Cohesion Programme, 2004. 
Beyme, Klaus von, "Right-Wing Extremism in Post-War Europe",

West European Politics, vol. 11, núm. 2, 1988, pp. 1-18.

Bjørklund, Tor, "The Radical Right in Norway: The Development

of the Progress Party", en Nora Langenbacher y Britta Schellenberg (eds.), Is Europe on the "Right» Path? Right-Wing Extremism and Right-Wing Populism in Europe, Berlín, Friedrich Ebert Stiftung-Forum Berlin-Project Combating Right-wing Extremism, 2011.

y Jørgen G. Andersen, "Anti-Immigration Parties in Denmark and Norway: The Progress Parties and the Danish People's Party", en Martin Schain, Aristide Zolberg y Patrick Hossay (eds.), Shadows over Europe: The Development and Impact of the Extreme Right in Western Europe, Nueva York, Palgrave Macmillan, 2002, pp. 107-136.

Breton, Albert, Gianluigi Galeotti, Pierre Salmon y Ronald Wintrobe (eds.), Political Extremism and Rationality, Nueva York, Cambridge University Press, 2002.

Connor, Walker, Ethnonationalism: The Quest for Understanding, Princetown, University Press, 1994.

Eatwell, Roger, "The Rebirth of the «Extreme Right» in Western Europe?”, Parliamentary Affairs, vol. 53, núm. 3, 2000, pp. 407-425.

Electograph, Sweden YouGov Poll, 2018, en https:/ / www.electograph.com/2018/03/sweden-yougov-poll-for-metro-march-2018. html

Eurostat, "Eurobarometer Interactive", 2017, en http://ec.europa. $\mathrm{eu} /$ commfrontoffice/publicopinion/index.cfm/Chart/index

García Olascoaga, Omar, Los partidos etnonacional populistas: una explicación para entender su comportamiento electoral en las democracias europeas contemporáneas, tesis, México, FCPYS-UnAm, 2016.

Golder, Matt, "Far Right Parties in Europe", The Annual Review of Political Science, vol. 19, 2016, pp. 477-497.

Ignazi, Piero, “The Silent Counter Revolution: Hypotheses on the Emergence of Extreme Right-wing Parties in Europe”, European Journal of Political Research, vol. 22, núm. 1, 1992, pp. 3-34.

Press, 2003.

Jungar, Ann-Cathrine, "Populism in the Nordic Countries: New 
Voices, Old Roots", en Hedwig Giusto, David Kitching y Stefano Rizzo (eds.), The Changing Faces of Populism, Bruselas, Foundation for European Progressive Studies, 2013.

Jupskås, Anders R., "The Progress Party: A Fairly Integrated Part of the Norwegian Party System?”, en Karsten Grabow y Florian Hartleb (eds.), Exposing the Demagogues. Right-wing and National Populist Parties in Europe, Bruselas, Konrad Adenauer Stiftung, 2013, pp. 205-236.

Kitschelt, Herbert y McGann, Anthony J., The Radical Right in Western Europe: A Comparative Analysis, Ann Arbor, University of Michigan Press, 1995.

Klein, Andreas M., "The End of Solidarity? On the Development of Right-wing Populist Parties in Denmark and Sweden”, en Karsten Grabow y Florian Hartleb (eds.), Exposing the Demagogues. Right-wing and National Populist Parties in Europe, Bruselas, Konrad Adenauer Stiftung, 2013.

Lipset, Seymour M. y Rokkan, Stein, "Cleavage Structures, Party Systems, and Voter Alignments: An Introduction”, en Seymour M. Lipset y Stein Rokkan (eds.), Party Systems and Voter Alignments: Cross-National Perspectives, Nueva York, The Free Press, 1967, pp. 1-64.

Meret, Susi, "From the Margins to the Mainstream? The Development of the Radical Right in Denmark", en Nora Langenbacher y Britta Schellenberg (eds.), Is Europe on the «Right» Path? Right-Wing Extremism and Right-Wing Populism in Europe, Berlín, Friedrich Ebert Stiftung-Forum Berlin-Project Combating Right-wing Extremism, 2011.

Midlarsky, Manus I., Origins of Political Extremism. Mass Violence in the Twentieth Century and Beyond, Cambridge, University Press, 2011.

Morgan, Philip, Fascism in Europe, 1919-1945, Londres, Routledge, 2003.

Mudde, Cas, The Ideology of the Extreme Right, Manchester, University Press, 2000.

, Populist Radical Right Parties in Europe, Cambridge, University Press, 2007.

(ed.), Political Extremism, Londres, Sage, 2014. 
Nolte, Ernst y Gustau Muñoz, "Un pasado que no quiere pasar. Una conferencia que, ya escrita, no pudo ser pronunciada", Pasajes. Revista de pensamiento contemporáneo, núm. 24, 2007, pp. 71-75.

oecd, How's Life? 2015. Measuring Well-being, París, oecd Publishing, 2015, en http://www.oecd.org/statistics/how-s-life-2308 9679.htm

Pankowski, Rafal, The Populist Radical Right in Poland: The Patriots, Londres, Routledge, 2011.

Pempel, T. J. (ed.), Uncommon Democracies: The One Party Dominant Regimes, Nueva York, Cornell University Press, 1990.

Polk, Jonathan et al., Chapel Hill Expert Survey (CHES) 1999-2014, 2015, en http://ches.web.unc.edu/

Powell, G. Bingham, "Extremist Parties and Political Turmoil: Two Puzzles", American Journal of Political Science, vol. 30, núm. 2, 1986, pp. 358-359.

Raunio, Tapio, "The Finns: Filling a Gap in the Party System”, en Karsten Grabow y Florian Hartleb (eds.), Exposing the Demagogues. Right-Wing and National Populist Parties in Europe, Bruselas, Konrad Adenauer Stiftung, 2013, pp. 133-160.

Rydgren, Jens, "Radical Right Populism in Sweden: Still a Failure, But for How Long?", Scandinavian Political Studies, vol. 25, núm. 1, 2002, pp. 27-56.

-, The Populist Challenge: Political Protest and Ethno-nationalist Mobilization in France, Nueva York, Berghahn, 2004.

— From Tax Populism to Ethnic Nationalism: Radical Right-Wing Populism in Sweden, Nueva York, Berghahn Books, 2006. - y Patrick Ruth, "Voting for the Radical Right in Swedish Municipalities: Social Marginality and Ethnic Competition?", Scandinavian Political Studies, vol. 34, núm. 3, 2011, pp. 202-225. Sverigedemokraterna, Principprogram, 2011.

"Sweden's Moderates open to Sweden Democrats immigration deal", The Local, 7 de mayo de 2018, en https://www.thelocal. se/20180507/swedens-moderates-open-to-sweden-democratsimmigration-deal

Traverso, Enzo, "La fábrica del odio. Xenofobia y racismo en Europa”, Constelaciones, vol. 4, 2012, pp. 411-417. 
UnHCr, Global Trends. Forced Displacement in 2016, Ginebra, United Nations High Commissioner for Refugees, 2016, en en http:/ / www.unhcr.org/statistics/unhcrstats/5943e8a34/global-tren ds-forced-displacement-2016.html

Vergara, Daniel, "Rasismen i SD riksdagsgrupp", Expo, 12 de septiembre de 2014, en http://expo.se/2014/rasismen-i-sds-riksdagsgrupp_6635.html

Widfeldt, Anders, "Scandinavia: Mixed Success for the Populist Right”, Parliamentary Affairs, vol. 53, núm. 3, 2000, pp. 486-500.

_ , "A Fourth Phase of the Extreme Right? Nordic Immigration-critical Parties in a Comparative Context", NORDEUROPAforum, vol. 20, núm. 1, 2010, pp. 7-31.

- Extreme Right Parties in Scandinavia, Londres, Routledge, 2015.

Wieviorka, Michel, Le racisme, une introduction, París, La Découverte, 1998.

Wintrobe, Ronald, Rational Extremism. The Political Economy of Radicalism, Cambridge, University Press, 2006. 
